\title{
Functional systems of students' organism depending on physical fitness to physical load
}

\author{
Popel’ S.L. ${ }^{1}$, Pyatnychuk G.A. ${ }^{1}$, Pyatnichuk D.V. ${ }^{1}$, Maystruv V.V. ${ }^{1}$, Verboviy V.P. ${ }^{2}$, \\ Zemskaya N.A. ${ }^{1}$, Kryzhanivskaya A.F. ${ }^{1}$, Chovgan R.Ya. ${ }^{1}$ \\ ${ }^{1}$ Vasyl Stefanyk Precarpathian National University, Ukraine \\ ${ }^{2}$ National Academy of the Interior, Ukraine
}

\begin{abstract}
Purpose:

to study reaction of cardio vascular system and erythrocyte homeostasis in students with different fitness for physical load.

Material: $\quad$ we tested students ( $n=150$, from them $n=105$ - boys and $n=45-$ girls). дівчата). Measurements were fulfilled after maximal physical load on ergo meter (Kettler, German). The load was 2,7 W/kg.

Results: $\quad$ indicators of vegetative blood circulation's regulation depend on fitness level to maximal physical load. In 1st group students it manifested as sharp asymmetric indicators' reverse between sympathetic and para sympathetic regulation of blood circulation. Besides, there appear reversibly and irreversibly changed forms of erythrocytes in periphery blood. In 2nd group students maximal physical load causes higher indicators of sympathetic circuit. In 3rd group students, under maximal physical load we did not find asymmetry between sympathetic and para sympathetic blood circulation's regulation.

Conclusions: between changes of vegetative blood circulation's regulation and students' fitness to maximal physical load there are multidirectional vectors of organism's functional state. They manifest as natural changes of forms of periphery blood erythrocytes.

Keywords: functional state, vegetative regulation, blood circulation, erythrocytes, students.
\end{abstract}

\section{Introduction}

For sustaining of homeostasis continuous metabolism and energy exchange with environment are required [7, 8]. It ensures self-regulation of physiological functions and sustains life activity at optimal and relatively constant level. In this respect human organism is half closed thermodynamic system, which consists of different organs and tissues [30]. According to requirements of internal medium and organism action's stability in respect to external conditions two systems are used: vegetative nervous system (VNS) and endocrine system. The first realizes general regulation: with sympathetic and para sympathetic sectors. The second influences on all organism's cells with influence of hormones and biologically active substances. Integral system is [32] is Eritrean system, in which the effecting final link is erythrocyte (Ep).

The mentioned above VNS sectors have their own sensor components, which perceive physical and chemical indicators of internal medium. Ep is directly information form of alive, which plays the role of feedbacke between two regulation systems. Ep is a formation component of organism's functional system (OFS) in [30, 34].

M. Holcik [33], F. B. Jensen [34], H. Mairbäurl [44] devoted their works to Ep different morphological functional properties. It permits to predict OFS state under influence of the following: external and internal factors, not standard, stress or de-adaptation development of processes [36, 37].

In other works influence of walking training on iron metabolism [41]; influence of resistance to insulin reduction on ferritin concentration after trainings [40]; change of ultra-marathon runners' blood morphology

\footnotetext{
C) Popel' S.L., Pyatnychuk G.A., Pyatnichuk D.V., Maystruv V.V., Verboviy V.P., Zemskaya N.A., Kryzhanivskaya A.F.,

Chovgan R.Ya., 2017

doi:10.15561/20755279.2017.0607
}

and chosen biochemical parameters [35]; changes of pro-inflammation markers and lysine concentration in response to trainings $[31,39]$ are noted.

Extreme factors are connected with trainings loads and psycho-emotional stress. Extreme factors are such external factors of influence on human OFS [25, 27].

In such conditions there appears OFS tension, resulted in not saving expenditure of functional reserves and their quick exhaustion. The temporary dynamic of such changes is studied rather completely in different studies $[26,42]$.

However, such data are not systemized. The have not contain complex approach to studying of mechanisms of adaptive reaction's (OFS) formation [8, 49]. Even to less extent organism's reactions to extreme conditions and psycho-physical factors' influence on students' Ep are studied $[38,50]$. Insufficient attention to this problem [43, 45,46 ] can manifest in the future as reduction of mental and physical workability, weakening of educational processes' effectiveness. Besides, it can cause disorder of health and disharmony of students' health, who are differently prepared for physical loads $\left(\mathrm{PL}_{\max }\right)$.

As N.V. Ivanova [9] and B.P. Lisovskiy [13] note, in unfavorable conditions there are: reduction of sensitivity to extreme action on students' organism $\mathrm{PL}_{\max }$; reduction of OFS reserves to homeostasis restoration, caused by this factor.

In this respect cardio vascular system (CVS) and erythrocyte link of homeostasis are the weakest [1, 11]. Vegetative and neuro motor regulation of nervous muscular system (NMS) has a number of general systemic structural functional properties, which naturally reflect in state of Ep $[44,46]$. There is certain interest to influence of sympathetic and para sympathetic sectors of CNS on athletes' CVS. With it no attention is paid to homeostatic function of Ep and CVS reaction with $\mathrm{PL}_{\max }$ on students. 
The purpose of the work: to study reaction of cardio vascular system and erythrocyte homeostasis in students with different fitness for physical load.

\section{Material and methods}

Participants: The research was fulfilled in Vasyl Stefanyk Precarpathian National University and National Academy of Home Affairs (Ivano Frankovsk). We tested students $(n=150$, from them $n=105$ - boys and $n=45$ girls).

Students were divided into 3 groups. In $1^{\text {st }}$ groups students practiced physical culture from time to time $(\mathrm{n}=48)$.In $2^{\text {nd }}$ group students practiced physical culture regularly $(\mathrm{n}=68)$. In $3^{\text {rd }}$ group students practiced regularly different kinds of sports $(\mathrm{n}=34)$.

Organization of the research: The measurements were fulfilled within standard physical culture lesson. The measurements were fulfilled after maximal physical load on ergo meter (Kettler, German). The load was 2,7 W/kg.

With the help of program «CardioLab+» we fulfilled 5 minutes recording of R-R-cardio intervals. All data were processed with special program [29].

For studying of erythrocytes' conformation and biochemical properties we took capillary blood by protocol of glucose concentration in blood determination [46]. Sampling of material was fulfilled directly before $\mathrm{PL}_{\max }$ and 1-3 minutes after recreation period.

Hemoglobin concentration was studied by standard method. Erythrocytes' quantity was studied by unified calculation method in Goryayev chamber. Gematocrit was studied by micro-method with the help of application of standardized geparinized capillary [24]. Morphological study of erythrocytes was fulfilled on scanning electronic microscope «JEOL-25M-T220A» (Japan) as per commonly accepted methodic [28].

Statistical analysis: for statistical comparison of OFS indicators with $\mathrm{PL}_{\max }$ we used earlier calculated data [16].

Statistical processing of results we fulfilled with the help of program GrafPad Prism 4.0 (GrafPad Sowtware Inc., США). We used non parametric methods of the research (Wilcoxon, Manna-Whitney tests). Selective parameters have the following values: $\langle\mathrm{x}\rangle-$ mean arithmetic; $\mathrm{D}^{*}{ }_{<\mathrm{x}\rangle}-$ statistical dispersion: $\delta_{\langle\mathrm{x}\rangle}-$ mean square deviation; $\delta^{*}{ }_{<x>}-$ mean square deviation from mean arithmetic; $[\langle\mathrm{x}\rangle \pm \mathrm{dx}]-$ interval of confidence. The found changes were considered to be significant, when the received level was less that the level of confidence $(\mathrm{P}<0,05)$.

\section{Results}

It was found that generalized indicators of sympathetic nervous system's activity (ISNS) in respect to $\mathrm{PL}_{\max }$ in $1^{\text {st }}$ group students had mean arithmetic 4,5 . After $\mathrm{PL}_{\text {max }}$ this indicators was 15,1 . Indicators of para sympathetic nervous system's activity (PSNS) in respect to $\mathrm{PL}_{\text {max }}$ was 19,0. After $\mathrm{PL}_{\text {max }}$ this indicators was 4,7 (see table 3).

Vegetative system complex in $1^{\text {st }}$ group boys had characteristic changes: indicators ISNS increase 3,9 times and indicator of para sympathetic nervous system reduces nearly 4,8 times. The same changes were observed in girls of $1^{\text {st }}$ group: ISNS increases 3,2 time $s$ and indicator of para sympathetic nervous system reduces 2,3 times.

After $\mathrm{PL}_{\max }$ in $1^{\text {st }}$ group students we observed especially great changes by Bayevskiy's index [1]: in 5,8 times and in girls - 5,6 times. However, absolute indicators of girls $(223,4)$ were much less the of boys $(417,3)$.

The calculations' combined results of $1^{\text {st }}$ group are given in tables 1 and 2 .

Girl students of $2^{\text {nd }}$ group differ by ISNS and PSNS indicators. ISNS mean arithmetic values before and after PL ${ }_{\text {max }}$ were 4,0 and 6,7. PSNS indicators were: before $\mathrm{PL}_{\max }-16,2$ and after $\mathrm{PL}_{\text {max }}-10,5$ (see table 3 ). ISNS indicators of $2^{\text {nd }}$ group boys were: before $\mathrm{PL}_{\text {max }}-4,5$; after $\mathrm{PL}_{\max }-11,2(\mathrm{p}<0,05)$. PSNS indicators were: before $\mathrm{PL}_{\max }-16,8$; after $\mathrm{PL}_{\max }-6,8$ (see table 4). Comparing with $2^{\text {nd }}$ group girls, the boys' ISNS indicators are higher and PSNS indicators are lower (before and after $\mathrm{PL}_{\max }$ ). In boys we also observed reverse of ISNS and PSNS indicators in Table 1. Cardio-respiratory indicators of $1^{\text {st }}$ group girls’ functional system after physical load.

Table 1. Cardio-respiratory indicators of $1^{\text {st }}$ group girls' functional system after physical load

\begin{tabular}{|c|c|c|c|c|c|c|}
\hline \multicolumn{2}{|c|}{ Indicators } & \multirow{2}{*}{$\begin{array}{l}<x> \\
3,27\end{array}$} & \multirow{2}{*}{$\frac{D^{*}{ }_{<x>}}{4,33}$} & \multirow{2}{*}{$\begin{array}{l}\delta_{\langle x\rangle} \\
2,08\end{array}$} & \multirow{2}{*}{$\frac{\delta_{<x>}^{*}}{0,56}$} & \multirow{2}{*}{$\begin{array}{l}\langle x> \pm d x \\
2,07 ; 4,46\end{array}$} \\
\hline ISNS & Before load & & & & & \\
\hline & After load & 9,52 & 125,03 & 11,18 & 2,38 & 4,$59 ; 14,57$ \\
\hline \multirow[t]{2}{*}{ PSNS } & Before load & 17,13 & 22,78 & 4,77 & 1,28 & 14,$39 ; 19,87$ \\
\hline & After load & 8,26 & 14,71 & 3,83 & 0,81 & 6,$57 ; 9,95$ \\
\hline \multirow[t]{2}{*}{ HBR } & Before load & 83,8 & 165,23 & 12,85 & 3,43 & 76,$41 ; 91,19$ \\
\hline & After load & 99,69 & 693,86 & 26,34 & 5,61 & 88,$07 ; 111,3$ \\
\hline \multirow[t]{2}{*}{ ITB } & Before load & 40 & 306,67 & 17,51 & 4,68 & 29,$94 ; 50,06$ \\
\hline & After load & 223,34 & 67893,98 & 260,56 & 55,55 & 118,$4 ; 348,3$ \\
\hline \multirow[t]{2}{*}{$\mathrm{SPO}_{2}$} & Before load & 98,6 & 0,37 & 0,61 & 0,16 & 98,$25 ; 98,95$ \\
\hline & After load & 98,04 & 0,65 & 0,80 & 0,17 & 97,$7 ; 98,4$ \\
\hline
\end{tabular}

Notes: ISNS - contribution of sympathetic sector of CNS in organism's regulatory processes; ISNS - contribution of para sympathetic sector of CNS in organism's regulatory processes; ITB - index of tension by Bayevskiy, reflecting regulatory systems' tension and prevailing of central mechanisms over autonomous; $\mathrm{HBR}$ - hear beats rate; $\mathrm{SPO}_{2}-$ Oxy-hemoglobin concentration in blood \%. 
For $2^{\text {nd }}$ group girls such reversing is not characteristic. They have ISNS increase 1,5times and PSNS reduction 1,6 times.

$2^{\text {nd }}$ group boys have Bayevskiy's index increased 3,6 times. In $2^{\text {nd }}$ group girls its increment after $\mathrm{PL}_{\max }$ is only 2.4 times.

In $3^{\text {rd }}$ group the same dynamic is observed. But in $1^{\text {st }}$ and $2^{\text {nd }}$ group these indicators change to less extent.

Study of erythrocyte link showed that after $\mathrm{PL}_{\max }$ in $1^{\text {st }}$ group there is significant increase of hematocrit and hemoglobin $y(P<0,05)$. In $3^{\text {rd }}$ group (boys and girls) it happens against the background of erythrocyte quantity increase. It is facilitated by progressing of hemo-concentration. $\mathrm{PL}_{\max }$ in $2^{\text {nd }}$ group students causes reduction of periphery erythrocytes (PE) (in average by $15,3 \pm 1,25 \%, \mathrm{P}<0,05)$.

In $1^{\text {st }}$ group, comparing with $2^{\text {nd }}$ group, fig. 1 a, we found many reversibly and irreversibly changed forms of PE (see fig. 1 b). In $3^{\text {rd }}$ group erythrocytes after PL max remain nearly unchanged (see fig. $1 \mathrm{c}$ ).

Table 2. Cardio-respiratory indicators of $1^{\text {st }}$ group boys' functional system before and after physical load до і після фізичного навантаження

\begin{tabular}{|c|c|c|c|c|c|c|}
\hline \multicolumn{2}{|c|}{ Indicators } & \multirow{2}{*}{$\begin{array}{l}<x> \\
4,53\end{array}$} & \multirow{2}{*}{$\frac{\mathrm{D}_{<x>}}{14,77}$} & \multirow{2}{*}{$\frac{\delta_{\langle x\rangle}}{3,84}$} & \multirow{2}{*}{$\frac{\delta_{<x>}^{*}}{0,906}$} & \multirow{2}{*}{$\begin{array}{l}<x> \pm d x \\
2,63 ; 6,43\end{array}$} \\
\hline ISNS & Before load & & & & & \\
\hline & After load & 15,13 & 80,52 & 8,97 & 1,67 & 11,$72 ; 18,55$ \\
\hline \multirow[t]{2}{*}{ PSNS } & Before load & 19 & 33,15 & 5,76 & 1,36 & $16.15 ; 21,85$ \\
\hline & After load & 4,73 & 18,73 & 4,33 & 0,8 & 3,$08 ; 6,38$ \\
\hline \multirow[t]{2}{*}{ HBR } & Before load & 81,26 & 181,56 & 13,47 & 3,17 & 74,$59 ; 87,93$ \\
\hline & After load & 116,9 & 393,16 & 19,83 & 3,68 & 109,$5 ; 124,5$ \\
\hline \multirow[t]{2}{*}{ ITB } & Before load & 71,05 & 4546,26 & 67,43 & 15,89 & 37,$68 ; 104,6$ \\
\hline & After load & 417,3 & 116366,1 & 341,12 & 63,35 & 287,$5 ; 547,2$ \\
\hline \multirow{2}{*}{$\mathrm{SPO}_{2}$} & Before load & 98,05 & 1,84 & 1,36 & 0,32 & 97,$38 ; 98,72$ \\
\hline & After load & 97,93 & 0,66 & 0,81 & 0,15 & 97,$62 ; 98,24$ \\
\hline
\end{tabular}

Notes: see table 1.

Table 3. Cardio-respiratory indicators of $2^{\text {nd }}$ group girls' functional system after physical load

\begin{tabular}{|c|c|c|c|c|c|c|}
\hline \multicolumn{2}{|c|}{ Indicators } & \multirow{2}{*}{$\begin{array}{l}<x> \\
4\end{array}$} & \multirow{2}{*}{$\begin{array}{l}*_{<x>}^{*} \\
12,76\end{array}$} & \multirow{2}{*}{$\begin{array}{l}\delta_{<x>} \\
3,55\end{array}$} & \multirow{2}{*}{$\begin{array}{l}\boldsymbol{\delta}_{<\mathrm{x}>} \\
1,17\end{array}$} & \multirow{2}{*}{$\begin{array}{l}<x> \pm d x \\
1,356,67\end{array}$} \\
\hline ISNS & Before load & & & & & \\
\hline & After load & 6,73 & 30,26 & 5,50 & 1,02 & 4,$64 ; 8,83$ \\
\hline \multirow[t]{2}{*}{ PSNS } & Before load & 16,17 & 38,33 & 6,12 & 1,98 & 11,$7 ; 20,63$ \\
\hline & After load & 10,46 & 30,38 & 5,51 & 1,02 & 8,$36 ; 12,6$ \\
\hline \multirow[t]{2}{*}{$\mathrm{HBR}$} & Before load & 87,55 & 103,69 & 10,07 & 3,33 & 79,$99 ; 95,12$ \\
\hline & After load & 99,3 & 359,41 & 18,95 & 3,52 & 92,$08 ; 106,5$ \\
\hline \multirow[t]{2}{*}{ ITB } & Before load & 73,89 & 4661,42 & 67,34 & 22,35 & 39,$43 ; 124,58$ \\
\hline & After load & 181,16 & 60986,1 & 246,9 & 45,85 & 87,$16 ; 275,2$ \\
\hline \multirow{2}{*}{$\mathrm{SPO}_{2}$} & Before load & 97,85 & 3,12 & 1,74 & 0,56 & 96,$57 ; 99,11$ \\
\hline & After load & 97,7 & 2,87 & 1,69 & 0,31 & 97,$05 ; 98,3$ \\
\hline
\end{tabular}

Notes: see table 1.

Table 4. Cardio-respiratory indicators of $2^{\text {nd }}$ group boys' functional system after physical load

\begin{tabular}{|c|c|c|c|c|c|c|}
\hline \multicolumn{2}{|c|}{ Indicators } & \multirow{2}{*}{$\begin{array}{l}<x> \\
4,5\end{array}$} & \multirow{2}{*}{$\begin{array}{l}{ }^{*}{ }_{<x>} \\
14,54\end{array}$} & \multirow{2}{*}{$\begin{array}{l}\delta_{\langle x\rangle} \\
3,55\end{array}$} & \multirow{2}{*}{$\begin{array}{l}{ }^{*}{ }_{<x>} \\
1,05\end{array}$} & \multirow{2}{*}{$\begin{array}{l}<x> \pm d x \\
2,17 ; 6,81\end{array}$} \\
\hline ISNS & Before load & & & & & \\
\hline & After load & 11,21 & 77,12 & 8,78 & 1,37 & 8,$47 ; 13,15$ \\
\hline \multirow[t]{2}{*}{ PSNS } & Before load & 16,82 & 45,89 & 6,76 & 1,99 & 12,$44 ; 21,2$ \\
\hline & After load & 6,80 & 24,01 & 4,90 & 0,76 & 5,$28 ; 8,34$ \\
\hline \multirow[t]{2}{*}{ HBR } & Before load & 86,5 & 92,48 & 11,72 & 3,47 & 78,$86 ; 94,1$ \\
\hline & After load & 105,17 & 152,95 & 12,37 & 1,93 & 101,$3 ; 109,0$ \\
\hline \multirow[t]{2}{*}{ ITB } & Before load & 72,77 & 7233,2 & 72,43 & 21,66 & 25,$17 ; 120,3$ \\
\hline & After load & 260,47 & 48623,59 & 220,51 & 34,44 & 191,$6 ; 329,4$ \\
\hline \multirow{2}{*}{$\mathrm{SPO}_{2}$} & Before load & 98,29 & 0,54 & 0,69 & 0,2 & 97,$85 ; 98,74$ \\
\hline & After load & 97,5 & 1,29 & 1,14 & 0,178 & 97,$14 ; 97,86$ \\
\hline
\end{tabular}

Notes: see table 1. 
Table 5. Cardio-respiratory indicators of $3^{\text {rd }}$ group boys' functional system before and after physical load

\begin{tabular}{|c|c|c|c|c|c|c|}
\hline \multicolumn{2}{|c|}{ Indicators } & \multirow{2}{*}{$\begin{array}{l}<x> \\
4,14\end{array}$} & \multirow{2}{*}{$\begin{array}{l}\frac{D^{*}}{\langle x\rangle} \\
15,22\end{array}$} & \multirow{2}{*}{$\frac{\delta_{\langle x\rangle}}{3,9}$} & \multirow{2}{*}{$\begin{array}{l}\delta^{*}{ }_{\langle x>} \\
0,85\end{array}$} & \multirow{2}{*}{$\frac{\langle x\rangle \pm d x}{2,48 ; 5,8}$} \\
\hline ISNS & Before load & & & & & \\
\hline & After load & 10,92 & 113,03 & 10,63 & 2,17 & 6,$45 ; 15,39$ \\
\hline \multirow[t]{2}{*}{ PSNS } & Before load & 16,09 & 59,29 & 7,7 & 1,68 & 12,$8 ; 19,38$ \\
\hline & After load & 9,92 & 36,47 & 6,04 & 1,23 & 7,$38 ; 12,46$ \\
\hline \multirow[t]{2}{*}{ HBR } & Before load & 77,47 & 180,86 & 13,44 & 2,93 & 71,$72 ; 83,22$ \\
\hline & After load & 99,16 & 200,77 & 14,17 & 2,89 & 93,$2 ; 105,11$ \\
\hline \multirow[t]{2}{*}{ ITB } & Before load & 53,80 & 2592,26 & 50,91 & 11,11 & 32,$03 ; 75,57$ \\
\hline & After load & 221,3 & 47233,0 & 217,3 & 44,36 & 129,$9 ; 312,7$ \\
\hline \multirow[t]{2}{*}{$\mathrm{SPO}_{2}$} & Before load & 98,14 & 1,52 & 1,23 & 0,26 & 97,$62 ; 98,66$ \\
\hline & After load & 97,52 & 1,37 & 1,17 & 0,238 & 97,$03 ; 98,01$ \\
\hline
\end{tabular}

Notes: see table 1.

In students athletes we observed increase of EP aggregation ability (content of aggregates increased by $15,0 \%$ ) and rising of their deformation coefficient (by $18,0 \%$ ), caused by muscular work (see fig. 1 ).

\section{Discussion}

For finding of CNS and Er reactions we used structural functional study of EP and automatic data analysis. We used variation pulse metering and rhythm cardio monitoring. Analysis of results showed that VNS activity is determined by results of control of organism's vegetative system's regulation: by reaction of CNS and EP $[16,47]$. Here the most feasible parameter of regulation process is rhythm of heart beat. Dynamic characteristics of heart beats rate permit to assess sympathetic and para sympathetic disorders in students' state [48].

Heart beat rate is easy to be registered. It reflects vegetative regulation processes [10, 16, 23]. With it HBR is indirect characteristic. It reflects regulation result at different OFS levels [15].

Different combinations of VNS links, ensuring vegetative homeostasis can correspond to one and the same HBR [6]. Tonus weakening of VNS para sympathetic sector can be followed by reduction of sympathetic sector's activity: with average HBR remaining constant $[1,20]$. HBR change under stress appear earlier than hormonal and biochemical disorders. It is conditioned by the fact that nervous system's reaction goes in advance of humoral factors. It permits to timely find stress reaction's peculiarities including to EP under physical load [29]. Cardio interval metering is one of modern methods of myocardium and organism's in general diagnostic [48]. It can be used for the following: characteristic of heart condition; organism's adaptive potential in selecting for different kinds of sports; control of life provisioning processes in training and competition periods [23].

The conducted earlier studied showed [25, 50], that at the end of academic year students athletes have low functional state of organism. It requires more careful attention to their physical condition.
$\mathrm{PL}_{\max }$ of different intensity plays important role in formation organism's general endurance [37]. It reflects general level of human workability. Endurance integrates great number of processes, which take place at different levels - from cell to the whole organism [18]. In most cases leading role in studying of endurance is played by finding factors, facilitating activation of energetic exchange and vegetative functions of its provisioning: cardio-respiratory and central nervous systems. With it study of cells' reactions under PL ${ }_{\text {max }}$ (EP, in particular) are remaining out of attention $[37,38]$.

EP is a convenient object for such kinds of researches. EP participate in sustaining of homeostasis at level of the whole organism [34, 44, 45]. These cells can participate in regulation of acid-alkaline and water electrolite balance, on micro-reological blood status. That is why with intensive $\mathrm{PL}_{\max }$ it is interesting in students' OFS regulation [36, 49, 50].

We found that in $57,0 \%$ if $1^{\text {st }}$ group students, under $\mathrm{PL}_{\text {max }}$ There appear negative morphological changes of EP. It is conditioned by metabolic disorders. The basis of such changes is exhaustion of organism's biosystem's functional potentials. It happens under negative influence of increased mental and physical loads of academic year $[26,27]$.

The received data witness that under $\mathrm{PL}_{\max }$ High requirements are set to $1^{\text {st }}$ group's students' organism (to energy supply systems and heart's external work. High external work of heart can be explained by prevailing of systolic blood pressure (BPs), which is accompanied by increase of myocardium demand in oxygen [18].

It was found that under $\mathrm{PL}_{\max }$ in boys changes of VNS indicators are more significant, comparing with girls. It can be explained by insufficient physical fitness of girls and specific reactions of female organism to academic loads $[8,9,15]$.

The received by us data show that VNS indicators $\mathrm{i}$ $3^{\text {rd }}$ group witness about students' better adaptation to changing conditions: the better is physical fitness, the higher are OFS compensatory mechanisms as well as 


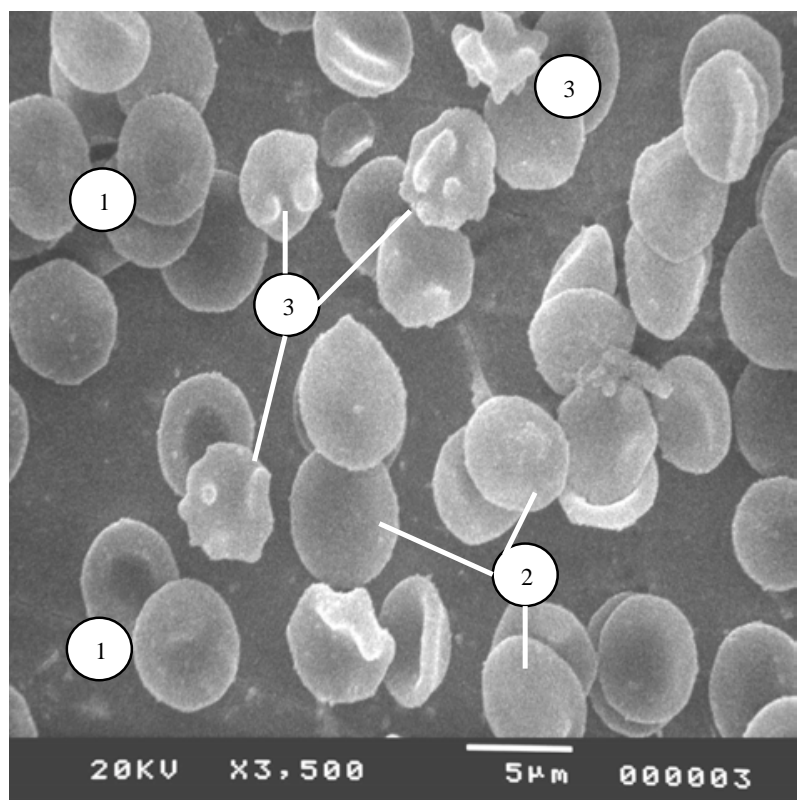

a

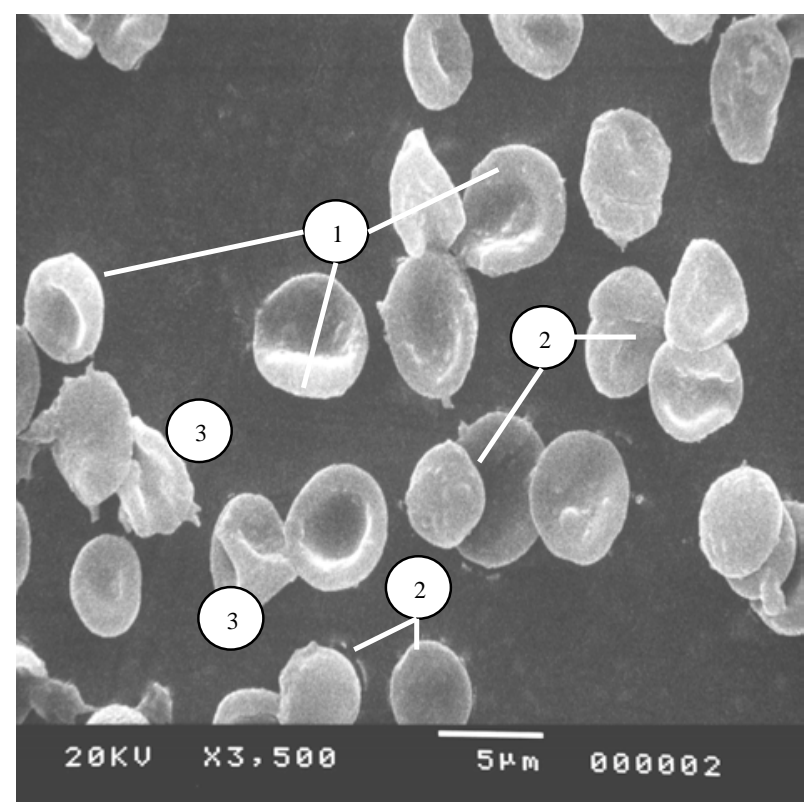

b

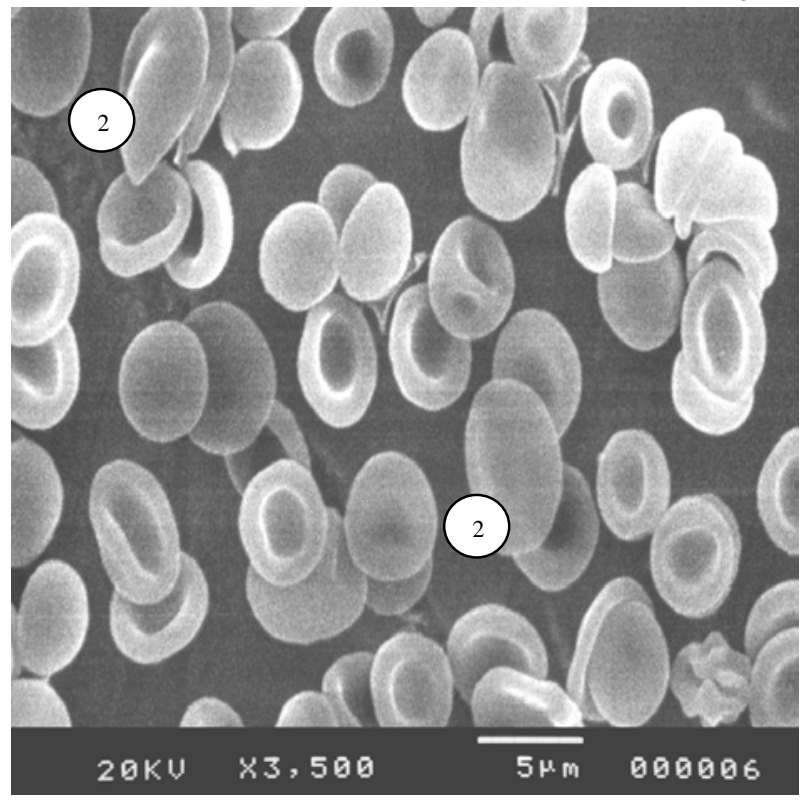

C

Fig. 1. Structural reconstruction of periphery erythrocytes in $1^{\text {st }}$ group (a), $2^{\text {nd }}$ group (b) and $3^{\text {rd }}$ group (c) after single maximal physical load. Legend: 1 - normal forms of erythrocytes; 2 - reversibly changed forms of erythrocytes; 3 irreversibly changed forms of erythrocytes. Method: scanning electronic microscopy (scale 3500:1).

organism's adaptation to environment is quicker [1, 3].

Specific feature of students' athletes' hemo-dynamic reacting to $\mathrm{PL}_{\max }$ is active work of mechanisms of blood circulation's periphery regulation. It is connected with strengthening of local blood flow [2, 4, 15]. The main mechanism of sustaining HBR low level is contracting abilities of left ventricle. With it general periphery resistance of vessels is low. Hearts of $1^{\text {st }}$ group students work in not effective regime. That is why its compensatory potentials are limited. For these students high ISNS indicators are also characteristic. In homeostasis sustaining tonus of artery link dominates. As per our research general periphery resistance is high, while the power of left ventricle is minimal [1]. This type of blood circulation is the least effective and has low adaptation potential [18].

As a number of authors note $[6,9,10]$, human organism, depending on type of VNS on blood circulation, reacts to $\mathrm{PL}_{\max }$ in complex way: changes in CNS work compulsory manifest also by changes of EP. When comparing ISNS values under $\mathrm{PL}_{\max }$ we noticed a tendency to increase of changed EP forms. Independent on students' groups, under $\mathrm{PL}_{\max }$ we observed changed EP indicators. However, comparing with relaxed state they increase only in $1^{\text {st }}$ group (2,46 times) and $2^{\text {nd }}$ group $(1,79$ times, $\mathrm{p}<0,05$ ).

By results of work of A. Ebner et al. [28], J. GonzálezAlons [32], F. B. Jensen [36] it is known that the quantity 
of circulating EP is one of factors for determination of blood rheological properties. Change of these indicators under $\mathrm{PL}_{\max }$ can substantially influence on oxygen transportation blood function. Such change can result in disorders in microcirculation system. It changes students' OFS level.

Such phenomenon is conditioned by influence of factors, which accompany muscular activity. They include increased blood circulation, rising of temperature and acidosis [38, 44, 46].

Under such conditions disorder of EP wholeness appears, which can result in "anemia of load" [46]. Such changes influence negatively on somatic health, physical workability and educational progress of students.

All these require appropriate correction of training process and working out of adequate measures, directed on elimination of possible pathologies in students' organism, depending on their fitness to $\mathrm{PL}_{\max }$

\section{Conclusions}

1. Depending on students' fitness to $\mathrm{PL}_{\text {max }}$ cardiohemo-dynamic non uniformity of blood circulation manifests in the form of different indicators of blood circulation's vegetative regulation.
2. In the process of adaptation to maximal physical load in $1^{\text {st }}$ group we observed sharp asymmetric reverse of indicators between sympathetic and para sympathetic regulation of blood circulation. With it, periphery link of blood circulation's regulation starts actively work. It manifests by emersion of reversibly and irreversibly changed forms of periphery erythrocytes.

3.Reacting of blood circulation system in $2^{\text {nd }}$ group to maximal physical load manifests in gender distinctions of blood circulation vegetative regulation: boys demonstrated higher indicators of sympathetic circuit and lower - of para sympathetic one. It conditions symmetric reverse of these indicators before and after physical load. It depends on the presence of increased quantity of reversibly changed forms of periphery erythrocytes.

4. In $1^{\text {st }}$ group, under maximal physical load we observed insignificant rising of sympathetic level and a little bit rising of para sympathetic one. It manifests as insignificant increase of quantity of deformed erythrocytes, without reduction of their sixes.

\section{Conflict of interests}

The authors state that there is no conflict of interest.

\section{References}

1. Baevskij RM. Theoretical substantiation of modern approaches to assessment of cardio-vascular system's adaptation reactions. Moscow: Medicine; 2009. (in Russian)

2. Bojchenko KIu. Study of sportswomen's functional state with the help of new methodic approaches. Slobozhanskij naukovo-sportivnij visnik, 2014;2:38-41. (in Russian)

3. Bosenco AI, Samokih II, Strashko SV, Orlik NA, Petrovsky EP. Evaluation of junior courses students' level of mobilization of functional backlogs at the dosed physical activities at the pedagogical university. Pedagogics, psychology, medicalbiological problems of physical training and sports, 2013;11:3-9. doi:10.6084/m9.figshare.815867

4. Getmancev S, Bogush V, Iacuns'kij O. Indicators of sportsmen's functional state in game kinds of sports. Sportivnij visnik Pridniprov'ia, 2010;3:50-54. (in Ukrainian)

5. Dovganik MS, Chichkan OA, Strel'chenko VV, Iavors'kij OG. Changes in cardio-vascular systems of men and women during long term health related run practicing. Slobozhanskij naukovo-sportivnij visnik, 2014;2:76-79. (in Ukrainian)

6. Zapovitriana EB, Korobeynikov GV, Korobeinikova LG. Peculiarities of vegetative regulation of heart rate in wrestlers of different age groups. Pedagogics, psychology, medicalbiological problems of physical training and sports, 2015; 19(4): 22-26. doi:10.15561/18189172.2015.0404

7. Zakharov VM, Trofimov IE. Homeostatic mechanisms of biological systems: homeostasis of development. Ontogenez, 2014;45(3):138-150. doi:10.7868/s0475145014030100

8. Es'kov VM, Khadarcev AA. Systemic analysis, monitoring and processing of information in biology and medicine. Samara: Etching; 2005. (in Russian)

9. Ivanova NV. Factors, determining functional state of sportsmen's cardio-respiratory system (cyclic kinds of sports). Slobozhanskij naukovo-sportivnij visnik, 2013;5(38):108111. (in Russian)

10.Korkushko OV. Methods of analysis and age standards of heart beats rate variability. Kiev; 2008. (in Russian)

11.Levchenko VA. Indexes of hemodynamics in a dosage of physical activity in girls against the background of low systolic blood pressure. Pedagogics, psychology, medicalbiological problems of physical training and sports, 2015; 19(2): 43-46. doi:10.15561/18189172.2015.0207

12.Lisiak VM. Functional changes in women's organism, practicing fitness aerobics. Slobozhanskij naukovo-sportivnij visnik, 2014;3:53-56. (in Ukrainian)

13.Lisovs'kij B. Functional reserves of cardio-respiratory system as indicators of human health. Visnik Prikarpats'kogo universitetu, 2006;2:31-34. (in Ukrainian)

14.Malikov MV, Bogdanovs'ka NV, Svat'iev AV. Functional diagnostic in physical education and sports. Zaporozhye: ZNU; 2006. (in Ukrainian)

15.Mikhajlov VM. Testing load under ECG control. Ivanovo; 2005. (in Russian)

16.Mickan BM, Popel' SL, Mickan MA. Methods of physical condition, physical fitness and somatic health of schoolchildren's research. Ivano-Frankivsk; 2000. (in Ukrainian)

17.Popel' SL, Tsap IG, Yatciv YaN, Lapkovsky EYi, Pyatnichuk DV. Special aspects of hemo-dynamic and reaction of erythrocytes in blood to standard physical load of different qualification female volleyball players. Pedagogics, psychology, medical-biological problems of physical training and sports, 2017; 21(5): 41-45. doi:10.15561/18189172.2017.05

18.Romanenko VA. Diagnostic of human organism's functional abilities. Donetsk: Donetsk National University; 2005. (in Russian)

19.Svat'iev AV, Malikov MV. Functional diagnostic in physical education and sports. Zaporozhye: ZSU; 2004. (in Ukrainian)

20.Serdyuk IV. Results of study of indexes of arteriotony for students. Pedagogics, psychology, medical-biological problems of physical training and sports, 2012;1:105-108. 
21.Serorez T. The indicators of the physical health of students on the characteristics of the physical fitness, aerobic and anaerobic productivity of their body. Pedagogics, psychology, medical-biological problems of physical training and sports, 2014; 18(9): 54-59. doi:10.5281/zenodo.10129

22.Serorez TB, Navka PI. Methodical features dispensing exercise, used in extracurricular activities to improve health students. Pedagogics, psychology, medical-biological problems of physical training and sports, 2014; 18(5): 60-66. doi:10.6084/m9.figshare.971065

23.Cekhmistro LM. Adaptation of cardio-vascular system to physical loads in elite sportsmen of cyclic kinds of sports. Slobozhanskij naukovo-sportivnij visnik, 2013;5:266-270. (in Ukrainian)

24.Abdelha MAK, Abdelmotta S. Biochemical Changes of Hemoglobin and Osmotic Fragility of Red Blood Cellsin High Fat Diet Rabbits. Pakistan Journal of Biological Sciences. 2010;13(2):73-77. doi:10.3923/pjbs.2010.73.77

25.Barker D, Wallhead T, Quennerstedt M. Student learning through interaction in physical education. European Physical Education Review. 2016;4:1-6. doi:10.1177/1356336x16640235

26.Brock SJ, Rovegno I, Oliver KL. The influence of student status on student interactions and experiences during a sport education unit. Physical Education \& Sport Pedagogy. 2009;14(4):355-375. doi:10.1080/17408980802400494

27.Chen S, Nam YH. Energy balance education in schools. European Physical Education Review. 2016;4:1-5. doi:10.1177/1356336x16641661

28.Ebner A, Schillers H, Hinterdorfer P. Normal and pathological erythrocytes studied by atomic force microscopy. Methods mol. biol. 2011;736:223-241.

29.Fuks AI, Elderer J, Ellemunter H. Cardiology clearance index: Normal values, repeatability, and reproducibility in Cardiology system-healthy children. Pediatric Cardiology. 2010;43(12):1180-1185.

30.Garaeva G, Vatamova S, Filatov M. Theory of Chaos and Self-Organization in Description of Functional Human Body Systems. Journal of New Medical Technologies. 2014;21(2):15-20. doi:10.12737/4989

31.Gmiat A, Mieszkowski J, Prusik K, Prusik K, Kortas J, Kochanowicz A, et al. Changes in pro-inflammatory markers and leucine concentrations in response to Nordic Walking training combined with vitamin D supplementation in elderly women. Biogerontology 2017:1-14. doi:10.1007/s10522017-9694-8

32.González-AlonsoJ.ATPasamediatoroferythrocyte-dependent regulation of skeletal muscle blood flow and oxygen delivery in humans. Journal of Physioljgy. 2012;590(20):5001-5013. doi:10.1113/jphysiol.2012.235002

33.Holcik M. Do mature red blood cells die by apoptosis? Trends in Genetics. 2001;18(3):121-126. doi:10.1016/s01689525(02)02652-5

34.Ignat'eva SN, Kubasov RV. Metabolic adaptation resources of organism to studying at medical university students in european north. Annals of the Russian Academy of Medical Sciences. 2014;69:11-12. doi:10.15690/vramn.v69i1112.1188

35.Jastrzębski Z, Zychowska M, Jastrzębska M, Prusik K, Prusik K, Kortas J, et al. Changes in blood morphology and chosen biochemical parameters in ultra-marathon runners during a $100-\mathrm{km}$ run in relation to the age and speed of runners. International Journal of Occupational Medicine and
Environmental Health, 2015;29(5): 801-814. doi:10.13075/ ijomeh.1896.00610

36.Jensen FB. The dual roles of red blood cells in tissue oxygen delivery: oxygen carriers and regulators of local blood flow. Journal of Experimental Biology. 2009;212(21):3387-3393. doi:10.1242/jeb.023697

37.Kang M. Should the physical educator be held accountable for student physical activity levels beyond physical education?. Physical Education, Recreation \& Dance. 2016;87(6):5556. doi:10.1080/07303084.2016.1192930

38.Karle H. Destruction of erythrocytes during experimental fever. Acta Medica Scandinavica. 2009;186(1-6):349-359. doi:10.1111/j.0954-6820.1969.tb01487.x

39.Kortas J, Kuchta A, Prusik K, Prusik K, Ziemann E, Labudda $\mathrm{S}$, et al. Nordic walking training attenuation of oxidative stress in association with a drop in body iron stores in elderly women. Biogerontology 2017: 1-8. doi:10.1007/s10522-0179681-0

40.Kortas J, Prusik K, Flis D, Prusik K, Ziemann E, Leaver $\mathrm{N}$, et al. Re: Possible effect of decreased insulin resistance on ferritin levels after Nordic Walking training. Clinical Interventions in Aging, 2016;11:150-151.

41.Kortas J, Prusik K, Flis D, Prusik K, Ziemann E, Leaver N. Effect of nordic walking training on iron metabolism in elderly women. Clinical Interventions in Aging, 2015;10:1889-1896.

42.Lambert MI. General Adaptations-Exercise: Acute Versus Chronic and Strength Versus Endurance Training. Exercise and Human Reproduction. London: Heidelberg Dordrecht; 2016.

43.Lorente-Catalan E, Kirk D. Student teachers understanding and application of assessment for learning during a physical education teacher education course. European Physical Education Review. 2015;22(1): 65-81. doi:10.1177/1356336x15590352

44.Mairbäurl H. Red blood cells in sports: effects of exercise and training on oxygen supply by red blood cells. Frontiers in Physiology, 2013;4:34-36. doi:10.3389/fphys.2013.00332

45.Mikhaylova LA. Central hemodynamics indices in senior pupils with increased educational and motive loading. Siberian Medical Review. 2013;3:55-58. doi:10.20333/250001362013-3-55-58

46.Mohanty JG, Nagababu E, Rifkind JM. Red blood cell oxidative stress impairs oxygen delivery and induces red blood cell aging. Frontiers in Physiology. 2014;5:1-5. doi:10.3389/fphys.2014.00084

47.Sassen B, Cornelissen VA, Kiers H. Physical fitness matters more than physical activity in controlling cardiovascular disease risk factors. European Journal of Cardiovascular Prevention \& Rehabilitation. 2009;16(6):677-683.

48.Soares-Miranda L, Sandercock G, Valente H. Vigorous physical activity and vagal modulation in young adults. European Journal of Cardiovascular Prevention \& Rehabilitation. 2009;16(6):705-711.

49. Tan Y, Sun D, Wang J. Mechanical characterization of human red blood cells under different osmotic conditions by robotic manipulation with optical tweezers. IEEE Transactions on Biomedical Engineering. 2010. Vol. 57, № 7. P. 816-1825. doi.org/10.1109/tbme.2010.2042448.

50. Zhu X. Student perspectives of grading in physical education. European Physical Education Review. 2015;21(4)409-420. doi:10.1177/1356336x15569628 
Information about the authors:

Popel' S.L.; http://orcid.org/0000-0002-2161-535X; popelsergij@gmail.com; Vasyl Stefanyk Precarpathian National University; 57 Shevchenko Str., Ivano-Frankivsk, 76018, Ukraine.

Pjatnichuk G.O.; http://orcid.org/0000-0001-6328-4168; pdva@i.ua; Vasyl Stefanyk Precarpathian National University; 57 Shevchenko Str., Ivano-Frankivsk, 76018, Ukraine.

Pjatnichuk D.V.; http://orcid.org/0000-0003-4668-9491; pdva@i.ua; Vasyl Stefanyk Precarpathian National University; 57 Shevchenko Str., Ivano-Frankivsk, 76018, Ukraine.

Maystruk V.V., http://orcid.org/0000-0002-9487-3923; antoshka7909@gmail.com; Vasyl Stefanyk Precarpathian National University; 57 Shevchenko Str., Ivano-Frankivsk, 76018, Ukraine.

Verbovuy V.P.; http://orcid.org/0000-0002-5004-4170; verbovuyif@ukr.net; National Academy of the Interior; 3 The National Guard str., Ivano-Frankivsk, 76018, Ukraine.

Zemska N.O.; http://orcid.org/0000-0002-8169-9954; zemskanadia@gmail.com; Vasyl Stefanyk Precarpathian National University; 57 Shevchenko Str., Ivano-Frankivsk, 76018, Ukraine.

Kryzanivskaya O. F.; http://orcid.org/0000-0003-4934-3840; ksenja6791@6791gmail.com; Vasyl Stefanyk Precarpathian National University; 57 Shevchenko Str., Ivano-Frankivsk, 76018, Ukraine.

Chovhan R. Ya.; http://orcid.org/0000-0003-4168-1773; rostikchovhan@gmail.com; Vasyl Stefanyk Precarpathian National University; 57 Shevchenko Str., Ivano-Frankivsk, 76018, Ukraine.

Cite this article as: Popel' SL, Pyatnychuk GA, Pyatnichuk DV, Maystruv VV, Verboviy VP, Zemskaya NA, Kryzhanivskaya AF, Chovgan RYa. Functional systems of students' organism depending on physical fitness to physical load. Physical education of students, 2017;21(6):302-309. doi:10.15561/20755279.2017.0607

The electronic version of this article is the complete one and can be found online at: http://www.sportedu.org.ua/index.php/PES/issue/archive

This is an Open Access article distributed under the terms of the Creative Commons Attribution License, which permits unrestricted use, distribution, and reproduction in any medium, provided the original work is properly cited (http://creativecommons.org/licenses/by/4.0/deed.en).

Received: 20.06.2017

Accepted: 15.07.2017; Published: 08.12.2017 